\title{
Rotifer Diversity in the Acidic Pyrite Mine Pit Lakes in the Sudety Mountains (Poland)
}

\author{
Agnieszka Pociecha ${ }^{1}$ (1) - Irena Bielańska-Grajner ${ }^{2}$ Ewa Szarek-Gwiazda ${ }^{1}$. \\ Elżbieta Wilk-Woźniak ${ }^{1} \cdot$ Hanna Kuciel $^{1} \cdot$ Edward Walusiak $^{1}$
}

Received: 6 September 2016 / Accepted: 13 October 2017 / Published online: 23 October 2017

(c) The Author(s) 2017. This article is an open access publication

\begin{abstract}
The diversity of rotifers was studied in three artificial water bodies (Azure Lake, Yellow Lake, and Purple Lake), which were once pyrite mines. The physicochemical parameters and the zooplankton composition of the water were determined. Azure Lake had a $\mathrm{pH}$ of 3.4-6.9, conductivity values of $165-194 \mu \mathrm{S} \mathrm{cm}^{-1}$, and low concentrations of sulphate, calcium, magnesium, copper, and iron, while the other lakes had a pH of 2.6-2.9, a conductivity of 1636-3400 $\mu \mathrm{S} \mathrm{cm}^{-1}$, and high concentrations of sulphate (up to $2863 \mathrm{mg} \mathrm{dm}^{-3}$ ), $\mathrm{Cu}$ (up to $2650 \mu \mathrm{g} \mathrm{dm}^{-3}$ ), and $\mathrm{Fe}$ (up to $178.3 \mathrm{mg} \mathrm{dm}^{-3}$ ). The rotifer community in the lakes comprised 27 taxa (15 in Azure Lake, 13 in Purple Lake and 14 in Yellow Lake). We also found two species that are rarely observed in Poland (Aspelta cincinator and Elosa spinifera), and three species commonly found in acidic water (E. worallii, Cephalodella delicata, and C. hoodi). The types of rotifers in Azure Lake differed from those in the other two lakes. The Shannon-Weaver biodiversity index $\left(\mathrm{H}^{\prime}\right)$ was the highest in Purple Lake $\left(\mathrm{H}^{\prime}=1.255\right)$ and lowest in Azure Lake $\left(\mathrm{H}^{\prime}=0.455\right)$. The effect of some of the physicochemical parameters on rotifer diversity is discussed.
\end{abstract}

Keywords Shannon-Weaver index $\cdot$ Mining excavations · Water chemistry $\cdot \mathrm{pH}$

Agnieszka Pociecha

pociecha@iop.krakow.pl

1 Institute of Nature Conservation, Polish Academy of Sciences, Av. A. Mickiewicza 33, 31-120 Kraków, Poland

2 Hydrobiology Department, University of Silesia, ul. Bankowa 9, 40-009 Katowice, Poland

\section{Introduction}

The chemistry of water that fills former mining excavations can vary greatly depending on the type of mine (e.g. pyrite, sulphur, coal, or metal ores), which creates specific conditions, such as high conductivity or low $\mathrm{pH}$ (Frömmichen et al. 2004; Blodau 2006; Lund and McCullough 2009; Jersabek et al. 2011; Geller et al. 2012, 2013). There have been relatively few studies on the organisms living in various post-mining water bodies, as these studies are difficult to conduct and require specialized techniques (Woelfl and Whitton 2000). However, researchers have begun to describe the organisms that live in these environments (Derham 2004; Geller et al. 2012, 2013; Ciszewski et al. 2013; Wołowski et al. 2013; Sienkiewicz and Gasiorowski 2015). There is a relatively large number of reports on the subject of the species diversity and physiology of cyanobacteria and algae (DeNicola 2000; Gross 2000; Lessmann et al. 2000; Steinberg et al. 2012; Wołowski et al. 2008, 2013; Lessman and Nixdorf 2013), protists and fungi (Geller et al. 2013; WendtPotthoff 2013), but fewer publications on the diversity of small animals including rotifers and cladocerans (Horyath and Hummon 1980; Deneke 2000; DeNicola 2000; Belyaeva and Deneke 2013; Ferrari et al. 2015).

The limited available information was not sufficient to define the role of planktonic animals in the food web of acidic mine lakes, which differ from that of more conventional lakes (Weinthoff et al. 2013). Rotifera are one of the most important groups present in mining lakes (Horyath and Hummon 1980; Deneke 2000; DeNicola 2000; Wollmann et al. 2000). Previous studies have shown that acidic pit lakes are dominated by only a few species, including Cephalodella hoodi, Rotaria rotatoria, Elosa worallii, C. gibba, and Brachionus sericus (Deneke 2000). The aim of this study was to investigate rotifer diversity and determine the effects of 
water properties on the rotifer community in three acidic pit lakes, created from abandoned pyrite opencast mines, in the Sudety Mountains in southern Poland. We hypothesized that the low $\mathrm{pH}$ and high metal concentrations would result in a low diversity of rotifers.

\section{Materials and Methods}

\section{Study Area}

"Colorful lakelets" is the name given to four artificial ponds that formed in an abandoned pyrite mine in the Rudawy Janowickie range of the Sudety Mountains in southwest Poland. These locations were mined for pyrite from 1785 to 1925 . The color of the lake water depends on the chemical composition of the banks and beds, which are high in iron and copper compounds (Uzarowicz and Skiba 2011; Uzarowicz et al. 2008, 2011). The lakelets consist of: Azure Lake (also known as blue or emerald, $635 \mathrm{~m}$ above sea level, $50^{\circ} 49^{\prime} 22,4^{\prime \prime} \mathrm{N} 15^{\circ} 58^{\prime} 18,7^{\prime \prime} \mathrm{E}$ ); Purple Lake (560 m above sea level, 50 $49^{\prime} 41,6^{\prime \prime} \mathrm{N} 15^{\circ} 58^{\prime} 26,1^{\prime \prime} \mathrm{E}$ ); Yellow Lake (555 m above sea level, $50^{\circ} 49^{\prime} 43,1^{\prime \prime} \mathrm{N} 15^{\circ} 58^{\prime} 26,5^{\prime \prime} \mathrm{E}$ ); and Green Lake ( $730 \mathrm{~m}$ above sea level, $\left.50^{\circ} 49^{\prime} 18,2^{\prime \prime} \mathrm{N} 15^{\circ} 58^{\prime} 0,1^{\prime \prime} \mathrm{E}\right)$. Depending on rainfall, Green Lake can temporarily disappear, which was the case during our study. The Azure Lake is fed by a small woodland stream, but the two remaining water bodies are supplied only by precipitation. Azure Lake is the largest, with a depth of approximately $11 \mathrm{~m}$, length of $150 \mathrm{~m}$, width of 30-40 m, and a surface area of $1770 \mathrm{~m}^{2}$. Purple Lake has an irregular shape, and is approximately $4 \mathrm{~m}$ deep in the central part; the length of the pit is $430 \mathrm{~m}$, the width is about $10 \mathrm{~m}$, and the surface area is $1290 \mathrm{~m}^{2}$. Yellow Lake is round in shape and is the smallest of the four lakes. It has a diameter of about $30 \mathrm{~m}$, a surface area of $280 \mathrm{~m}^{2}$, and a maximum depth of about $6 \mathrm{~m}$ (Fig. 1) (Uzarowicz and Skiba 2011; Uzarowicz et al. 2008, 2011).

\section{Water and Rotifer Sampling}

Samples for physicochemical and biological parameter analyses were taken from the deepest sampling points of the Azure, Yellow, and Purple Lakes in Spring (May-June) and Autumn (August-September) of 2011 and 2012. Samples were also collected at two other depths in each lakelet: Azure Lake, surface water and $5 \mathrm{~m}$; Yellow Lake, surface water and $3 \mathrm{~m}$; and Purple Lake, surface water and $2 \mathrm{~m}$. Year 2011 was wet, but 2012 was dry, during which the water level of Purple and Yellow lakes fell by over a meter. Some physicochemical water properties $[\mathrm{pH}$, temperature, electrical conductivity (EC), and dissolved oxygen (DO)] were measured in situ using a multi-parameter probe (6600V2; YSI Inc., Yellow Springs, OH, USA). Samples for chemical analysis

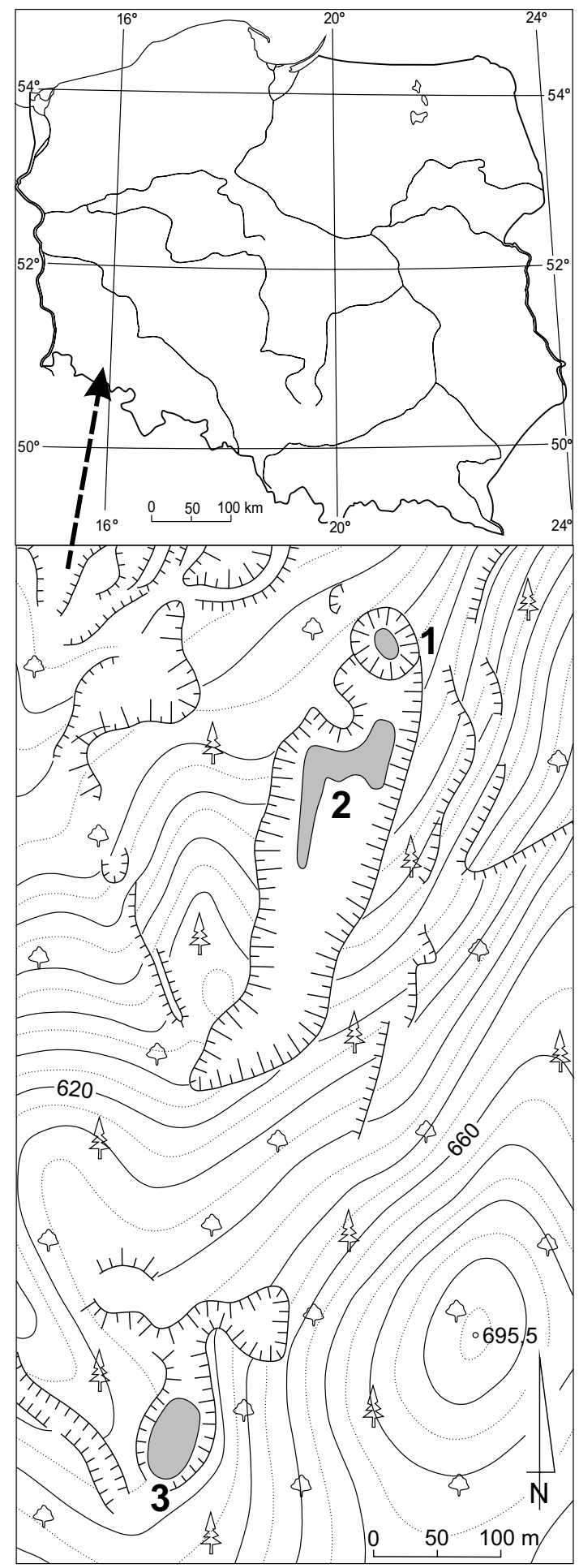

Fig. 1 Map of the sampling sites in the "Colorful Lakelets" formed in an abandoned pyrite mine in the Rudawy Janowickie range of the Sudety Mountains (south-west Poland): 1 Yellow Lake, 2 Purple Lake, 3 Azure Lake

were collected from the same points and layers as biological samples, and immediately transported to the laboratory. 
Anions $\left(\mathrm{Cl}^{-}, \mathrm{SO}_{4}{ }^{2-}, \mathrm{HCO}_{3}{ }^{-}\right.$, and $\left.\mathrm{NO}_{3}{ }^{-}\right)$and cations $\left(\mathrm{Mg}^{2+}\right.$, $\mathrm{Ca}^{2+}, \mathrm{K}^{+}$, and $\mathrm{Na}^{+}$) were analyzed using ion chromatography (ICS-1000 IC25 ion chromatograph; Dionex, Sunnyvale, CA, USA). Water analyzed for metals (total concentrations of $\mathrm{Cd}, \mathrm{Pb}, \mathrm{Cu}, \mathrm{Zn}, \mathrm{Mn}, \mathrm{Fe}, \mathrm{Ni}$, and $\mathrm{Cr}$ ) were first acidified to $\mathrm{pH} 2$ with ultrapure $\mathrm{HNO}_{3}$, then analyzed using atomic absorption spectrophotometry (AA20; Varian, Mulgrave, Victoria, Australia).

Samples collected from the lakes were used to assess rotifer composition. For the quality and quantity analyses, the rotifers were concentrated from $30 \mathrm{~L}$ of water with a $30 \mu \mathrm{m}$ plankton net, then fixed with $4 \%$ formalin. These subsamples were analyzed under a light microscope (Eclipse 50i; Nikon, Tokyo, Japan) at 100-400 $\times$ magnification. The composition and density of rotifers was determined by counting, using $0.5 \mathrm{~mL}$ Kolkwitz chambers. The rotifer density in $1 \mathrm{~L}$ of water was counted and the mean value was calculated from five counts. Taxonomic zooplankton analyses were conducted using the identification keys described by Nogrady et al. (1995); Segers (1995); Norgady and Segers (2002), Ejsmont-Karabin et al. (2004).

The Shannon-Weaver and evenness indexes of species diversity were calculated using MVSP software. To determine the relationship between the physicochemical and biological parameters, the Pearson correlation coefficient was calculated. The differences between lakes for the physicochemical and biological parameters were analyzed using the Mann-Whitney test with Statistica 12 software (StatSoft Inc., Tulsa, OK, USA).

\section{Results}

\section{Water Chemistry}

The temperature of the water during spring and late summer of 2011 and 2012 ranged from 9 to $15^{\circ} \mathrm{C}$ (Table 1). The lakes can be divided into two groups: strongly acidic water characterized by a pH of 2.6-2.9, as observed in the Purple and Yellow Lakes; and acidic or neutral water, with a $\mathrm{pH}$ of 3.4-6.8, as observed in Azure Lake (Table 1). The water of Azure and Yellow Lakes were well oxygenated, while Purple Lake usually was weakly oxygenated (Table 1 ). The differences in DO content of the lakes were significant (Table 2).

The lakes also differed in their salt concentration, as expressed by their EC. The highest EC was in Purple Lake (up to $3400 \mu \mathrm{S} \mathrm{cm}^{-1}$ ), while the lowest was determined in Azure Lake (up to $194 \mu \mathrm{S} \mathrm{cm}^{-1}$ ). In each lake, the dominant
Table 1 The values of physicochemical parameters and heavy metal concentrations in the water of 'Colourful lakelets'

\begin{tabular}{|c|c|c|c|c|c|c|c|}
\hline \multirow[t]{2}{*}{ Parameter } & \multirow[t]{2}{*}{ Unit } & \multicolumn{2}{|l|}{ Azure L. } & \multicolumn{2}{|c|}{ Purple L. } & \multicolumn{2}{|c|}{ Yellow L. } \\
\hline & & Median & Range & Median & Range & Median & Range \\
\hline Depth & $\mathrm{m}$ & & $7.5-8.1$ & & $2.3-3.0$ & & $2.0-4.5$ \\
\hline Temperature & ${ }^{\circ} \mathrm{C}$ & & $9.5-13.4$ & & $11.9-15.0$ & & $11.4-13.3$ \\
\hline Conductivity & $\mu \mathrm{S} \mathrm{cm}{ }^{-1}$ & 171 & $165-194$ & 2580 & $2040-3400$ & 1685 & $1636-1789$ \\
\hline $\mathrm{pH}$ & & 4.9 & $3.4-6.9$ & 2.7 & $2.6-2.9$ & 2.7 & $2.6-2.8$ \\
\hline Dissolved oxygen & $\mathrm{mg} \mathrm{dm} \mathrm{m}^{-3}$ & 9.3 & $8.5-10.0$ & 4.9 & $0.0-8.2$ & 13.2 & $10.5-13.7$ \\
\hline $\mathrm{Cl}^{-}$ & $\mathrm{mg} \mathrm{dm}^{-3}$ & 2.3 & $2.3-4.1$ & 3.9 & $3.0-7.5$ & 4.5 & $3.0-5.2$ \\
\hline $\mathrm{HCO}_{3}^{-}$ & $\mathrm{mg} \mathrm{dm}^{-3}$ & 8.4 & $0.7-9.2$ & 36.2 & $1.4-61.4$ & 29.6 & $1.0-37.1$ \\
\hline $\mathrm{SO}_{4}{ }^{2-}$ & $\mathrm{mg} \mathrm{dm}^{-3}$ & 74.7 & $61.1-84.8$ & 1340.6 & $1118-2863$ & 710.4 & $629.3-871.5$ \\
\hline $\mathrm{NO}_{3}{ }^{-}$ & $\mathrm{mg} \mathrm{dm}^{-3}$ & 0.41 & $0.24-1.21$ & 0.25 & $0.06-0.56$ & 0.58 & $0.04-0.91$ \\
\hline $\mathrm{PO}_{4}^{3-}$ & $m g \mathrm{dm}^{-3}$ & 0.02 & $0.00-0.03$ & 0.22 & $0.01-0.76$ & 0.38 & $0.00-0.71$ \\
\hline $\mathrm{Na}^{+}$ & $\mathrm{mg} \mathrm{dm}^{-3}$ & 3.5 & $2.4-4.5$ & 5.8 & $5.0-7.0$ & 4.8 & $4.7-5.8$ \\
\hline $\mathrm{K}^{+}$ & $\mathrm{mg} \mathrm{dm}^{-3}$ & 0.4 & $0.3-0.9$ & 2.0 & $0.4-3.1$ & 1.0 & $0.8-2.3$ \\
\hline $\mathrm{Ca}^{2+}$ & $\mathrm{mg} \mathrm{dm}^{-3}$ & 17.2 & $15.6-19.8$ & 214.6 & $198.9-306.7$ & 149.7 & $116.9-172.5$ \\
\hline $\mathrm{Mg}^{2+}$ & $\mathrm{mg} \mathrm{dm}^{-3}$ & 7.2 & $6.6-8.1$ & 135.2 & 114.5-201.8 & 52.0 & $40.2-60.0$ \\
\hline $\mathrm{NH}_{4}^{+}$ & $\mathrm{mg} \mathrm{dm}^{-3}$ & 0.04 & $0.01-0.08$ & 0.23 & $0.06-0.34$ & 0.17 & $0.14-0.39$ \\
\hline $\mathrm{Cd}$ & $\mu \mathrm{g} \mathrm{dm}{ }^{-3}$ & 0.4 & $0.3-1.2$ & 3.7 & $3.0-6.4$ & 1.2 & $0.7-1.7$ \\
\hline $\mathrm{Pb}$ & $\mu \mathrm{g} \mathrm{dm}{ }^{-3}$ & 0.5 & ND-1.2 & 2.1 & $1.3-5.6$ & 1.0 & $0.9-1.3$ \\
\hline $\mathrm{Cu}$ & $\mu \mathrm{g} \mathrm{dm}^{-3}$ & 8.9 & $4.9-12.1$ & 1027.5 & $326-2650$ & 240 & $205-257$ \\
\hline $\mathrm{Zn}$ & $\mu \mathrm{g} \mathrm{dm}^{-3}$ & 32.5 & $12-43$ & 267.5 & $75-503$ & 67.5 & $53-108$ \\
\hline $\mathrm{Cr}$ & $\mu \mathrm{g} \mathrm{dm}^{-3}$ & 0.5 & $0.1-1.1$ & 72.9 & $17.4-140.0$ & 29.3 & $20.8-135$ \\
\hline $\mathrm{Ni}$ & $\mu \mathrm{g} \mathrm{dm}^{-3}$ & 10.2 & $6.4-22.0$ & 196.7 & $71-370$ & 50.0 & $39.9-86.0$ \\
\hline $\mathrm{Mn}$ & $\mathrm{mg} \mathrm{dm}^{-3}$ & 0.14 & $0.12-0.16$ & 1.7 & $0.36-3.5$ & 0.4 & $0.33-0.47$ \\
\hline $\mathrm{Fe}$ & $\mathrm{mg} \mathrm{dm}^{-3}$ & 0.11 & $0.07-0.56$ & 84.7 & $28.8-178.3$ & 29.5 & $26.1-35.9$ \\
\hline
\end{tabular}

$N D$ not detected 
Table 2 Significance differences in the values of physicochemical parameters, heavy metal concentrations of the water and the density of chosen rotifers taxons between studied lakes (Mann-Whitney test) ( $Z$ statistic value; $p$ level of significance; $n s$ not significant)

\begin{tabular}{|c|c|c|c|c|c|c|}
\hline \multirow{3}{*}{$\begin{array}{l}\text { Physicochemical and biological } \\
\text { parameters }\end{array}$} & \multicolumn{6}{|l|}{ Lakes } \\
\hline & \multicolumn{2}{|c|}{ Azure-Purple } & \multicolumn{2}{|c|}{ Azure-Yellow } & \multicolumn{2}{|c|}{ Yellow-Purple } \\
\hline & $\mathrm{Z}$ & $\mathrm{p}$ & $\mathrm{Z}$ & $\mathrm{p}$ & $\mathrm{Z}$ & $\mathrm{p}$ \\
\hline $\mathrm{pH}$ & 3.18 & 0.0015 & 2.85 & 0.0043 & - & $\mathrm{ns}$ \\
\hline Dissolved oxygen & 3.18 & 0.0015 & -2.85 & 0.0043 & 2.76 & 0.0058 \\
\hline Conductivity & -3.18 & 0.0015 & -2.85 & 0.0043 & 2.76 & 0.0058 \\
\hline $\mathrm{Cl}^{-}$ & -2.72 & 0.0065 & -2.56 & 0.0104 & - & ns \\
\hline $\mathrm{SO}_{4}^{-}$ & -3.18 & 0.0015 & -2.85 & 0.0043 & 2.76 & 0.0058 \\
\hline $\mathrm{HCO}_{3}^{-}$ & - & ns & - & $\mathrm{ns}$ & - & $\mathrm{ns}$ \\
\hline $\mathrm{Na}^{+}$ & -3.18 & 0.0015 & -2.85 & 0.0043 & 2.11 & 0.035 \\
\hline $\mathrm{K}^{+}$ & -2.72 & 0.0065 & -2.56 & 0.0104 & - & $\mathrm{ns}$ \\
\hline $\mathrm{Ca}^{2+}$ & -3.18 & 0.0015 & -2.85 & 0.0043 & 2.76 & 0.0058 \\
\hline $\mathrm{Mg}^{2+}$ & -3.18 & 0.0015 & -2.85 & 0.0043 & 2.76 & 0.0058 \\
\hline $\mathrm{NO}_{3}^{-}$ & - & ns & - & ns & - & $\mathrm{ns}$ \\
\hline $\mathrm{PO}_{4}^{3-}$ & -2.49 & 0.0128 & -1.98 & 0.0481 & - & ns \\
\hline $\mathrm{Cd}$ & -3.31 & 0.0009 & -2.29 & 0.0219 & 2.63 & 0.0085 \\
\hline $\mathrm{Pb}$ & -3.31 & 0.0009 & -2.12 & 0.0338 & 2.38 & 0.0174 \\
\hline $\mathrm{Cu}$ & -3.31 & 0.0009 & -2.63 & 0.0085 & 2.63 & 0.0085 \\
\hline $\mathrm{Zn}$ & -3.31 & 0.0009 & -2.63 & 0.0085 & 2.29 & 0.0219 \\
\hline $\mathrm{Mn}$ & -3.31 & 0.0009 & -2.63 & 0.0085 & 2.29 & 0.0219 \\
\hline $\mathrm{Fe}$ & -3.31 & 0.0009 & -2.63 & 0.0085 & 2.12 & 0.0338 \\
\hline $\mathrm{Cr}$ & -3.31 & 0.0009 & -2.85 & 0.0043 & - & ns \\
\hline $\mathrm{Ni}$ & -3.31 & 0.0009 & -2.63 & 0.0085 & 2.46 & 0.0138 \\
\hline Bdelloidea-density & 2.20 & 0.028 & - & ns & - & ns \\
\hline Cephalodella hoodi-density & - & ns & -2.77 & 0.006 & - & ns \\
\hline Elosa worallii-density & - & ns & -2.28 & 0.023 & - & ns \\
\hline
\end{tabular}

anion was $\mathrm{SO}_{4}{ }^{2-}$. The dominant cations were $\mathrm{Ca}^{2+}$ in Azure and Yellow Lakes and $\mathrm{Ca}^{2+}$ and $\mathrm{Mg}^{2+}$ in Purple Lake (Table 1). The lake water was characterized by a low amount of nutrients $\left(\mathrm{NO}_{3}{ }^{-}, \mathrm{NH}_{4}{ }^{+}\right.$, and $\left.\mathrm{PO}_{4}{ }^{3-}\right)$, though higher concentrations of $\mathrm{NH}_{4}{ }^{+}$and $\mathrm{PO}_{4}{ }^{3-}$ ions were measured periodically in Purple and Yellow Lakes. The lake waters differed in the concentrations of the major anions, cations, and nutrients, with the exception of $\mathrm{HCO}_{3}{ }^{-}$and $\mathrm{NO}_{3}{ }^{-}$(Table 2). The water of Purple and Yellow Lakes had significantly higher EC values and concentrations of $\mathrm{Cl}^{-}, \mathrm{SO}_{4}{ }^{2-}, \mathrm{Na}^{+}$, $\mathrm{K}^{+}, \mathrm{Ca}^{2+}, \mathrm{Mg}^{2+}, \mathrm{NH}_{4}{ }^{+}$, and $\mathrm{PO}_{4}{ }^{3-}$ ions, compared to Azure Lake. Additionally, the Purple Lake water had significantly higher $\mathrm{EC}$ values and $\mathrm{SO}_{4}{ }^{2-}, \mathrm{Na}^{+}, \mathrm{Ca}^{2+}$, and $\mathrm{Mg}^{2+}$ content compared to Yellow Lake (Table 2). The concentrations of the major ions and nutrients was not significantly different between the upper and bottom layers in Yellow and Azure Lakes. However, the $\mathrm{SO}_{4}{ }^{2-}, \mathrm{Ca}^{2+}$, and $\mathrm{Mg}^{2+}$ content in Purple Lake was approximately 1.5 times greater at a depth of $5 \mathrm{~m}$ than at the surface (Table 1).

Concentrations of metals in the studied lakes varied widely (Table 1). The Azure Lake water had lower concentrations of $\mathrm{Cd}, \mathrm{Pb}, \mathrm{Zn}, \mathrm{Mn}$ and $\mathrm{Ni}$ (2-5-times lower), $\mathrm{Cu}$ (27 times lower), $\mathrm{Cr}$ (58 times lower), and Fe (268 times lower) than Yellow Lake water, and lower concentrations of $\mathrm{Cd}, \mathrm{Pb}$, and Zn (4-9-times lower), Mn and Ni (12-19 times lower), $\mathrm{Cu}$ and $\mathrm{Cr}$ (146-162 times lower), and Fe (770 times lower) than Purple Lake water. The differences in metal concentrations between the lakes (with the exception of $\mathrm{Cr}$ in Yellow and Purple lakes) were statistically significant (Table 2).

\section{Rotifers}

The density of Bdelloidea in Azure Lake was significantly higher than in Purple Lake, while C. hoodi and E. worallii were higher in Yellow Lake than in Azure Lake. The differences in rotifer density indicates that Bdelloidea prefer water with a higher $\mathrm{pH}$. Conversely, $C$. hoodi and $E$. worallii prefer water with a strongly acidic $\mathrm{pH}$. However, the low total density of rotifers in Purple Lake confirmed that the physicochemical water conditions were unsuitable (Tables 2, 3).

The zooplankton community of the three lakes consisted of 26 rotifer taxa; however, only four taxa were present in all of the studied lakes: Bdelloidea, Kellicottia longispina, Keratella cochlearis and $K$. quadrata. The greatest number of total taxa (15) was found in Azure Lake, with 13 found in 
Table 3 Taxonomical characteristics and density (ind $\mathrm{L}^{-1}$ ) of rotifers in studied lakes ( $\mathrm{x}-$ species were found in quality samples)

\begin{tabular}{|c|c|c|c|c|c|c|}
\hline \multirow[t]{2}{*}{ Taxa } & \multicolumn{2}{|c|}{ Azure L. } & \multicolumn{2}{|c|}{ Purple L. } & \multicolumn{2}{|c|}{ Yellow L. } \\
\hline & 2011 & 2012 & 2011 & 2012 & 2011 & 2012 \\
\hline \multicolumn{7}{|l|}{ Bdelloidea } \\
\hline Rotaria neptunia (Müll.) & $\mathrm{x}$ & & & & & \\
\hline Rotaria rotatoria (Müll.) & $\mathrm{x}$ & 3 & & & $\mathrm{x}$ & \\
\hline Bdelloidea n.d & 20 & 14 & 3 & & 3 & 9 \\
\hline \multicolumn{7}{|l|}{ Monogononta } \\
\hline Asplanchna priodonta Gosse & & 2 & & & & \\
\hline Aspelta cincinator (Gosse) & & & 1 & & & \\
\hline Brachionus angularis Gosse & & 2 & & & & 1 \\
\hline Brachionus diversicornis (Daday) & & & & 2 & & \\
\hline Brachionus rubens Ehrb & 6 & & 2 & & & \\
\hline Brachionus urceolaris (Müll.) & & 28 & & & & \\
\hline Cephalodella auriculata (Müll.) & & & & & 886 & \\
\hline Cephalodella catellina (Müll.) & & & & & 4 & \\
\hline Cephalodella delicata Wulfert & & & 7 & & & \\
\hline Cephalodella gibba Ehrb & & & & & 1 & \\
\hline Cephalodella hoodi (Gosse) & & & 3 & 10 & 99 & 48 \\
\hline Cephalodella ventripes (Dix.-Nutt.) & & & 9 & & 1 & \\
\hline \multicolumn{7}{|l|}{ Colurella colurus (Ehrb.) } \\
\hline Elosa worallii Lord & & & 52 & & 149 & 103 \\
\hline Gastropus stylifer Imh & & & & & 1 & \\
\hline Kellicottia longispina Kell & 1 & 688 & $\mathrm{x}$ & 16 & $\mathrm{x}$ & 20 \\
\hline Keratella cochlearis (Gosse) & 57 & & 1 & 4 & $\mathrm{x}$ & 2 \\
\hline Keratella tecta (Gosse) & 3 & 3 & 1 & & & \\
\hline Keratella quadrata (Müll.) & 5 & 24 & $\mathrm{x}$ & 3 & 20 & 1 \\
\hline Lecane levistyla (Olof.) & 1 & & & & & \\
\hline Lecane lunaris (Ehrb.) & 4 & & 1 & & & \\
\hline Lecane stichaea (Harr.) & $\mathrm{x}$ & 4 & & & & \\
\hline Polyarthra dolichoptera Idel & & & & & 2 & \\
\hline Testudinella patina (Herm.) & 5 & & & & & \\
\hline Trichocerca iernis (Gosse) & & & $\mathrm{x}$ & & & \\
\hline Trichocerca rattus (Müll.) & $\mathrm{x}$ & & & & & \\
\hline Total density of year & 102 & 768 & 80 & 35 & 1166 & 184 \\
\hline Total number of taxa & 13 & 9 & 13 & 5 & 13 & 7 \\
\hline Total number of taxa in whole seasons & 15 & & 13 & & 14 & \\
\hline
\end{tabular}

Purple Lake, and 14 in Yellow Lake. The numbers of rotifer taxa were higher in the first year than the second (Table 3).

Species composition and dominant taxa were different between lakes and study years. K. longispina were dominant in Azure Lake, with a high number of Bdelloidea n.d., Brachionus urceolaris, K. cochlearis, and Keratella quadrata. In Purple Lake, E. worallii were the dominant species, and $K$. longispina, C. hoodi, and Cephalodella ventripes were also numerous. Cephalodella auriculata, $E$. worallii, and $C$. hoodi dominated Yellow Lake, while $K$. longispina and $K$. quadrata were also present in high numbers. The densities of the remaining species were less than ten individuals per L, with sometimes only a few individuals per L (Table 3). Among the species found in the studied lakelets, we observed some rarely reported in Poland: Aspelta cincinator and $C$. delicata, as well as $C$. auriculata, C. delicata, C. hoodi, and E. worallii, which favour acidic water.

The highest Shannon $\left(\mathrm{H}^{\prime}\right)$ diversity rates (up to $<1$ ) and evenness of distribution rates (up to $<0.5$ ) occurred in Purple Lake in both years and Yellow Lake during the second year of investigation (Table 4). There were statistically significant correlations observed between the density of particular species and the physicochemical parameters of the water (Table $5 \mathrm{a}-\mathrm{c}$ ). In the Azure Lake, positive correlations were observed between specific species with the concentration of nutrients. Lecane stichaea was positively associated with $\mathrm{PO}_{4}{ }^{3-}$ and 
Table 4 Species richness, dominance, and indexes of diversity in studied mine lakes

\begin{tabular}{|c|c|c|c|c|c|c|}
\hline \multirow{2}{*}{$\begin{array}{l}\text { Lake } \\
\text { Year }\end{array}$} & \multicolumn{2}{|l|}{ Azure } & \multicolumn{2}{|l|}{ Purple } & \multicolumn{2}{|l|}{ Yellow } \\
\hline & 2011 & 2012 & 2011 & 2012 & 2011 & 2012 \\
\hline Dominant taxa & $\begin{array}{l}\text { Keratella } \\
\text { cochlearis } \\
56 \%\end{array}$ & $\begin{array}{l}\text { Kellicottia } \\
\text { longispina } \\
89 \%\end{array}$ & $\begin{array}{l}\text { Elosa } \\
\quad \text { worallii } \\
65 \%\end{array}$ & $\begin{array}{l}\text { Kellicottia } \\
\text { longispina } \\
45.7 \%\end{array}$ & $\begin{array}{l}\text { Cephalodella } \\
\text { auriculata } \\
75.9 \%\end{array}$ & $\begin{array}{l}\text { Elosa } \\
\text { worallii } \\
56 \%\end{array}$ \\
\hline $\mathrm{H}^{\prime}$ & 0.455 & 0.584 & 1.241 & 1.255 & 0.815 & 1.210 \\
\hline J & 0.198 & 0.281 & 0.539 & 0.780 & 0.354 & 0.622 \\
\hline
\end{tabular}

$\mathrm{NO}_{3}{ }^{-}$concentrations, $K$. quadrata with $\mathrm{NO}_{3}{ }^{-}$, and $K$. longispina with $\mathrm{PO}_{4}{ }^{3-}$. A negative correlation was found between Brachionus urceolaris and $\mathrm{NO}_{3}{ }^{-}$concentration. $K$. cochlearis and Keratella tecta showed negative correlations with $\mathrm{pH}$, while Branchionus rubens and Lecane lunaris were negatively correlated with the dissolved oxygen and hydrocarbonate content. The total density of rotifers and $K$. tecta was negatively correlated with $\mathrm{Ca}^{2+}$ content. While $K$. cochlearis and $K$. quadrata were positively correlated with conductivity, $B$. urceoralis showed a negative association. L. stichaea was positively correlated with sulphate concentrations. Among the rotifer species, positive correlations were found between Bdelloidea and $K$. tecta, B. rubens and L. lunaris, and between L. stichaea, K. longispina and K. quadrata (Table 5a).

In Purple Lake, E. worallii showed a negative correlation with $\mathrm{SO}_{4}^{2-}$ and a positive association with $\mathrm{K}^{+}$. Bdelloidea were negatively correlated with the DO and bicarbonate content, but were positively associated with $\mathrm{NH}_{4}{ }^{+}$. Positive relationships among rotifers living in strongly acidic conditions were found for $E$. worallii with $K$. longispina, A. cincinator, $C$. ventripes, and $K$. tecta, as well as between $C$. delicata and Bdelloidea (Table 5B).

In Yellow Lake, $K$. quadrata was positively correlated with $\mathrm{PO}_{4}{ }^{3-}$ and $\mathrm{Ca}^{2+}$ concentrations, while $K$. longispina was positively correlated with $\mathrm{SO}_{4}{ }^{2-}$, but negatively correlated with $\mathrm{K}^{+}$. Total rotifer density was positively correlated with the $\mathrm{Ca}^{2+}$ content (Table $5 \mathrm{C}$ ).

Some rotifers were positively correlated with particular metals. In Azure Lake, K. longispina and L. stichaea were positively associated with $\mathrm{Cr}$, K. tecta with $\mathrm{Pb}, B$. rubens and L. lunaris with $\mathrm{Ni}$, and $B$. urceolaris with Mn. In Yellow Lake, K. quadrata was positively associated with $\mathrm{Zn}$ and Fe. A positive relationship was found between total rotifer density and $\mathrm{Cr}$ in Azure Lake, while there was a positive correlation between the total rotifer density and the $\mathrm{Cd}$ and $\mathrm{Zn}$ content in Yellow Lake (Table 5A, C). In the highly contaminated Purple Lake, E. worallii was negatively correlated with $\mathrm{Ni}$. Lead, which was present in small amounts in Purple Lake, was positively correlated with total rotifer density (Table 5B).

\section{Discussion and Conclusion}

The chemistry of the water in these "colorful lakelets" was affected by their geochemical background and by the water supplying the lakes. In ecosystems like these, the biological communities are usually small, with low species diversity. There are typically no fish, and the role of top predator is taken over by invertebrates (Wollmann et al. 2000). While the composition of the zooplankton community is controlled by $\mathrm{pH}$ and related to water chemistry variables, the zooplankton biomass may be regulated by food availability (Wollmann et al. 2000; Moser and Weisse 2011). Based on their water chemistry, the studied lakes represent two clearly different groups. Azure Lake, situated higher than the other lakes and fed by a small rainwater stream and water from the degraded land surface, had water characterized by an acidic to neutral $\mathrm{pH}$ (3.4-6.9), and low EC and concentrations of major ions, nutrients, and metals such as $\mathrm{Fe}, \mathrm{Cu}$, $\mathrm{Cr}, \mathrm{Cd}$, and Ni. Conversely, the water of the Purple and Yellow lakes originates from rainwater that runs down the steep walls of the pyrite excavations, as well as from acidic water from neighboring adits, giving the water a strongly acidic $\mathrm{pH}$ (2.6-2.9) and significantly higher concentrations of the above parameters (with the exception of $\mathrm{HCO}_{3}{ }^{-}$and $\mathrm{NO}_{3}{ }^{-}$). The Azure and Yellow lakes have a sulphate-calcium water type, whereas the Purple Lake has sulphate-calcium-magnesium water. Similar results for water composition have been reported in the pit lakes of the Iberian Pyrite Belt, with characteristics ranging from circumneutral water with relatively low metal concentrations to extremely acidic and metal(oid)-rich water (España et al. 2008). Another study from a pyrite mine pond in Portugal found that the water had a low $\mathrm{pH}$ and high concentrations of some metals (Turnau et al. 2009).

The chemical composition of water from the "colorful lakelets" creates varied environmental conditions for the organisms that live there. The best physicochemical conditions for biota appeared to occur in Azure Lake, which had an acidic to neutral $\mathrm{pH}$ and a relatively low concentration of metals. The strongly acidic $\mathrm{pH}$ of the Purple and Yellow Lakes favors the occurrence of metals as free metal ions, which are more bioavailable and therefore, have a higher 
Table 5 Significant correlations between values of physico-chemical and biological parameters (Spearman's rank order, $\mathrm{p}<0.05)$ in the "Colourful lakelets" (A-Azure L.; B-Purple L.; C-Yellow L.)

\begin{tabular}{|c|c|c|c|c|c|c|c|c|c|c|}
\hline \multirow{2}{*}{$\begin{array}{l}\text { Parameters } \\
\text { (A) }\end{array}$} & \multirow[t]{2}{*}{$\begin{array}{l}\text { Bra- } \\
\text { chionus } \\
\text { rubens }\end{array}$} & \multirow[t]{2}{*}{$\begin{array}{l}\text { Brachionus } \\
\text { urceolaris }\end{array}$} & \multirow[t]{2}{*}{$\begin{array}{l}\text { Kellicottia } \\
\text { longispina }\end{array}$} & \multirow[t]{2}{*}{$\begin{array}{l}\text { Keratella } \\
\text { cochlearis }\end{array}$} & \multicolumn{2}{|c|}{ Keratella tecta } & $\begin{array}{l}\text { Keratella } \\
\text { quadrata }\end{array}$ & \multirow[t]{2}{*}{ Lecane lunaris } & \multirow[t]{2}{*}{ Lecane stichaea } & \multirow[t]{2}{*}{$\begin{array}{l}\text { Total density } \\
\text { of rotifers }\end{array}$} \\
\hline & & & & & & & & & & \\
\hline $\mathrm{Pb}$ & & & & & 0.73 & & & & & \\
\hline $\mathrm{Mn}$ & & 0.76 & & & & & & & & \\
\hline $\mathrm{Cr}$ & & & 0.76 & & & & & & 0.73 & 0.81 \\
\hline $\mathrm{Ni}$ & 0.76 & & & & & & & 0.76 & & \\
\hline Dissolved oxygen & -0.76 & & & & & & 0.93 & -0.77 & 0.77 & \\
\hline $\mathrm{pH}$ & & & & -0.87 & -0.76 & & & & & \\
\hline Conductivity & & -0.78 & & 0.71 & & & 0.71 & & & \\
\hline $\mathrm{SO}_{4}^{2-}$ & & & & & & & & & 0.76 & \\
\hline $\mathrm{HCO}_{3}^{-}$ & -0.76 & & & & & & & -0.76 & & \\
\hline $\mathrm{Ca}^{2+}$ & & & & & -0.77 & & & & & -0.71 \\
\hline $\mathrm{NO}_{3}^{-}$ & & -0.85 & & & & & 0.91 & & 0.76 & \\
\hline $\mathrm{PO}_{4}^{3-}$ & & & 0.87 & & & & & & 0.76 & \\
\hline Bdelloidea & & & & & 0.82 & & & & & \\
\hline Brachionus rubens & & & & & & & & 0.99 & & \\
\hline $\begin{array}{l}\text { Kellicottia long- } \\
\text { ispina }\end{array}$ & & & & & & & & & 0.88 & 0.79 \\
\hline $\begin{array}{l}\text { Keratella quad- } \\
\text { rata }\end{array}$ & & & & & & & & & 0.81 & 0.75 \\
\hline Lecane stichaea & & & & & & & & & & 0.76 \\
\hline Parameters & & $\begin{array}{l}\text { Aspelta cinci- } \\
\text { nator }\end{array}$ & Bdelloidea & $\begin{array}{l}\text { Cephalod } \\
\text { delicata }\end{array}$ & & $\begin{array}{l}\text { Cephaloc } \\
\text { ventripes }\end{array}$ & & osa worallii & Keratella tecta & $\begin{array}{l}\text { Total } \\
\text { density of } \\
\text { rotifers }\end{array}$ \\
\hline \multicolumn{11}{|l|}{ (B) } \\
\hline $\mathrm{Pb}$ & & & & & & & & & & 0.82 \\
\hline $\mathrm{Ni}$ & & & & & & & & 0.80 & & \\
\hline Dissolved oxygen & & & -0.76 & & & & & & & \\
\hline $\mathrm{SO}_{4}{ }^{2-}$ & & & & & & & & 0.80 & & \\
\hline $\mathrm{HCO}_{3}^{-}$ & & & -0.76 & & & & & & & \\
\hline $\mathrm{K}^{+}$ & & & & & & & & .76 & & \\
\hline $\mathrm{NH}_{4}^{+}$ & & & 0.80 & & & & & & & \\
\hline Cephalodella delic & & & 0.76 & & & & & & & \\
\hline \multicolumn{11}{|c|}{ Cephalodella gibba } \\
\hline Elosa worallii & & 0.76 & & & & 0.76 & & & 0.76 & \\
\hline \multicolumn{11}{|c|}{ Kellicottia longispina } \\
\hline Parameters & & & Kellicottia lc & ongispina & & & Kerate & ella quadrata & & $\begin{array}{l}\text { Total } \\
\text { density of } \\
\text { rotifers }\end{array}$ \\
\hline \multicolumn{11}{|l|}{ (C) } \\
\hline $\mathrm{Cd}$ & & & & & & & & & & 0.90 \\
\hline $\mathrm{Zn}$ & & & & & & & 0.89 & & & 0.90 \\
\hline $\mathrm{Fe}$ & & & & & & & 0.89 & & & \\
\hline $\mathrm{SO}_{4}^{2-}$ & & & 0.89 & & & & & & & \\
\hline $\mathrm{K}^{+}$ & & & -0.89 & & & & & & & \\
\hline $\mathrm{Ca}^{2+}$ & & & & & & & 0.89 & & & 0.90 \\
\hline $\mathrm{PO}_{4}^{3-}$ & & & & & & & 0.89 & & & \\
\hline
\end{tabular}


toxicity to organisms (Kushner 1993; Ciszewski et al. 2013). Complexes of metals with strong ligands, especially sulphates, found in high concentrations in the Yellow and Purple lakes, could potentially decrease this metal toxicity. The highest metal concentrations (with the exception of Cr) were found in the deeper water of Purple Lake, probably due to poor oxygenation (usually $<2 \mathrm{mg} \mathrm{dm}^{-3}$ ) and the low $\mathrm{pH}$, which favors the release of metals from an easily reductive phase (Calmano et al. 2005; Szarek-Gwiazda 2013) in the sediment to the overlying water. The positive correlations found between specific metals and the total density, or particular species, of rotifers in the Azure and Yellow lake water suggests that these metals were not toxic to these rotifers. The $\mathrm{Cu}$ and $\mathrm{Fe}$ concentrations in the Purple and Yellow lakes, and $\mathrm{Zn}$ in Purple Lake, were within the range determined to be lethal metal concentrations for freshwater rotifers. For example, the LC50 values for $\mathrm{Cu}$, determined to be toxic to Lecane hamata, L. luna, and $L$. quadridentata in laboratory experiments, were in the range of 0.06-0.33 $\mathrm{mg} \mathrm{dm}^{-3}$ (Pérez-Legaspi and Rico-Martínez 2001), the Zn LC50 value was reported to be $0.12 \mathrm{mg} \mathrm{dm}^{-3}$ for L. quadridentata (Guzmán et al. 2010), and the Fe LC50 for Daphnia magna was $23.78 \mathrm{mg} \mathrm{dm}^{-3}$ (Burba 1999). Therefore, it is expected that the $\mathrm{Cu}, \mathrm{Zn}$, and Fe levels would be toxic to some rotifers living in the Purple and Yellow lakes. Furthermore, the negative correlation observed between $\mathrm{Ni}$ and $E$. worallii in the highly contaminated Purple Lake may indicate its negative effect on this organism.

In Azure Lake, the rotifers identified were clearly different from those in the Purple and Yellow lakes. In Azure Lake, which has a higher $\mathrm{pH}$ and lower conductivity, the dominant species (K. longispina and $K$. cochlearis) are species that are common and widespread. There were no acidophilic rotifer species in this lake, and the total number of species was higher than in the other studied lakes. In general, we observed a relatively low number of rotifer taxa (27 in total) in the three water bodies. This has also been observed in other water ecosystems with low $\mathrm{pH}$, such as the identification of only one species in the most acidic Australian lake (Moser and Weisse 2011) and in an acidic meromictic lake in the Czech Republic (Hrdinka et al. 2013), three species in Chicken Creek lake (pH 2.4-2.9; Derham 2004), four taxa in an acidic uranium mine pit lake in Brazil (Ferrari et al. 2015), nine taxa in three acidic lakes in Lusatia Germany (pH 2-4; Wollmann et al. 2000), and 23 species in the Blue Waters, Stockton, and WO5B lakes (pH 3.9-4.4; Derham 2004). Substantially fewer rotifer species were found in an acidic quarry lake by Horyath and Hummon (1980). Most species observed in the lakes evaluated in our study are common and widely distributed, however, few of these species have been described as typically found at a low $\mathrm{pH}$. The most abundant taxa observed in the studied lakes, including C. auriculata, C. hoodi, E. worallii, and K. longispina, have also been observed in pit lakes with a $\mathrm{pH}<3$ (Nixdorf et al. 1998; Deneke 2000). Some of these species demonstrate specific strategies in order to function well in these ecosystems, and occupy different "vertical niche habitats" (Weinhoff 2004). According to some authors, a low pH is the most important factor limiting the diversity of water organisms. In such ecosystems, the structure of the food web is less complex (Wollmann et al. 2000). This hypothesis has been confirmed by Deneke (2000), who found a positive correlation between the number of zooplankton species and an average $\mathrm{pH}$ of 2.3-3.9 in 21 acidic pit lakes in the Lusatian region (Germany). Another study conducted in three lakes (Blue Waters, Stockton, and WO5B), all with a $\mathrm{pH}$ between 3.8-5, showed a low $\mathrm{H}^{\prime}$ index from 1.7 to 2.5 (Derham 2004). Our results also support this hypothesis. The Shannon-Weaver diversity index for the lakes included in this study was relatively low, ranging from 1.210 in Yellow Lake to 1.255 in Purple Lake, both of which have a low $\mathrm{pH}$ and high concentrations of some metals (especially $\mathrm{Cu}$ and $\mathrm{Fe}$ ), which adversely affected rotifer diversity.

Our results indicate that physicochemical parameters other than $\mathrm{pH}$ can potentially influence the diversity of some rotifer species, as demonstrated by positive or negative correlation with phosphate, nitrate, DO, bicarbonate, EC, sulphate, and calcium in Azure Lake, ammonium, potassium, sulphate, DO, and bicarbonate in Purple Lake, and phosphate, sulphate, potassium, and calcium in Yellow Lake. A similar observation was reported in coal mine water by Radwan and Paleolog (1983). Apart from $\mathrm{pH}$, the most important factors appeared to be chloride, sulphate, calcium, and DO, all of which affected the occurrence and quantitative structure of rotifer assemblages. High concentrations of sulphate, $\mathrm{Fe}, \mathrm{Ca}, \mathrm{Mg}, \mathrm{Mn}, \mathrm{Zn}, \mathrm{Cu}$, and $\mathrm{Cd}$ were shown to influence zooplankton species composition in other acidic pit lakes (Moser and Weisse 2011; Ferrari et al. 2015).

In conclusion, while the physicochemical parameters of the water showed considerable variability between the studied lakes, the $\mathrm{pH}$ and high concentration of some metals (especially $\mathrm{Cu}$ and $\mathrm{Fe}$ ) had the greatest effect on the composition of rotifer communities. The highest species diversity of rotifers was observed in the Yellow and Purple lakes, where the dominant species were acidophilic species.

Acknowledgements This work was supported by the Polish National Science Center (Project No. N305 374939) and co-funded by the Institute of Nature Conservation, Polish Academy of Sciences (Kraków, Poland). The authors are grateful to Proof-Reading-Service.com for their editing of the manuscript.

Open Access This article is distributed under the terms of the Creative Commons Attribution 4.0 International License (http:// creativecommons.org/licenses/by/4.0/), which permits unrestricted use, distribution, and reproduction in any medium, provided you give 
appropriate credit to the original author(s) and the source, provide a link to the Creative Commons license, and indicate if changes were made.

\section{References}

Belyaeva M, Deneke R (2013) The biology and ecosystems of acidic pit lakes. Zooplankton. In: Geller W, Schultze M, Kleinmann R, Wolkersdorfer C (eds) Acidic pit lakes. Springer, Berlin, pp 117-126

Blodau C (2006) A review of acidity generation and consumption in acidic coal mine lakes and their watersheds. Sci Total Environ 369:307-332

Burba A (1999) The design of an experimental system of estimation methods for effects of heavy metals and their mixtures on Daphnia magna. Acta Zool Litu Hydrobiol 9(2):21-29

Calmano W, von der Kammer F, Schwartz R (2005) Characterization of redox conditions in soils and sediments: heavy metals. In: Lens P, Grotenhuis T, Malina G, Tabak H (eds) Soil and sediment remediation. IWA Publ, London, pp 102-120

Ciszewski D, Aleksander-Kwaterczak U, Pociecha A, Szarek-Gwiazda E, Waloszek A, Wilk-Woźniak E (2013) Small effects of a large sediment contamination with heavy metals on aquatic organisms in the vicinity of an abandoned lead and zinc mine. Environ Monit Assess 185(12):9825-9842

Deneke R (2000) Review of rotifers and crustaceans in highly acidic environments of $\mathrm{pH}$ values $\leq 3$. Hydrobiologia 433:167-172

DeNicola DM (2000) A review of diatoms found in highly acidic environments. Hydrobiologia 433:111-122

Derham T (2004) Biological communities and water quality in acidic mine lakes. http://www.sese.uwa.edu.au/_data/assets/pdf_ file/0011/1637354/Derham_2004.pdf. Accessed 1 Nov 2004

Ejsmont-Karabin J, Radwan S, Bielańska-Grajner I (2004) Rotifers. Monogononta-atlas of species. Polish freshwater fauna. Univ of Łódź, Łódź, pp 77-447 (in Polish)

España JS, Pamo EL, Pastor ES, Ercilla MD (2008) The acidic mine pit lakes of the Iberian Pyrite Belt: an approach to their physical limnology and hydrogeochemistry. Appl Geochem 23:1260-1287

Ferrari CR, de Azevedo H, Wisniewski MJS, Rodgher S, Roque CV, Nascimento MRL (2015) An overview of an acidic uranium mine pit lake (Caldas, Brazil): composition of the zooplankton community and limnochemical aspects. Mine Water Environ 34(3):343-351

Frömmichen R, Wendt-Potthoff K, Freise K, Fischer R (2004) Microcosm studies for neutralization of hypolimnic acid mine pit lake water (pH 2.6). Environ Sci Technol 38:1877-1887

Geller W, Klapper H, Salomons W (eds) (2012) Acidic mining lakes: acid mine drainage, limnology and reclamation. Springer, Berlin

Geller W, Schultze M, Kleinmann B, Wolkersdorfer C (eds) (2013) Acidic pit lakes: the legacy of coal and metal surface mines. Springer, Berlin

Gross W (2000) Ecophysiology of algae living in highly acidic environments. Hydrobiologia 433:31-33

Guzmán FT, González FJA, Martínez RR (2010) Implementing Lecane quadridentata acute toxicity tests to assess the toxic effects of selected metals ( $\mathrm{Al}, \mathrm{Fe}$ and $\mathrm{Zn}$ ). Ecotoxicol Environ Safe 73:287-295

Horyath FJ, Hummon WD (1980) Influence of mine acid on planktonic rotifers. Ohio J Sci 80:1-140

Hrdinka T, Sobr M, Fott J, Nedbalova L (2013) The unique environment of the most acidified permanently meromictic lake in the Czech Republic. Limnologica 43:417-426
Jersabek CD, Weithoff G, Weisse T (2011) Cephalodella acidophila n. sp. (Monogononta: Notommatidae), a new rotifer species from high acidic mining lakes. Zootaxa 2939:50-58

Kushner DJ (1993) Effects of speciation of toxic metals on their biological activity. Water Pollut Res J Can 28:111-128

Lessman D, Nixdorf B (2013) The biology and ecosystems of acidic pit lakes: phytoplankton. In: Geller W, Schultze M, Kleinmann R, Wolkersdorfer C (eds) Acidic pit lakes. Springer, Berlin, pp 107-116

Lessmann D, Fyson A, Nixdorf B (2000) Phytoplankton of the extremely acidic mining lakes of Lusatia (Germany) with $\mathrm{pH} 3$. Hydrobiologia 433: 123-128

Lund MA, McCullough CD (2009) Limnology and ecology of low sulphate, poorly-buffered, acidic coal pit lakes in Collie, Western Australia. Proc, 10th International Mine Water Association (IMWA) Congress. http://www.imwa.info/docs/imwa_2008/ IMWA2008_183_Lund.pdf

Moser M, Weisse T (2011) The most acidic Austrian lake in comparison to a neutralized mining lake. Limnologica 41:303-315

Nixdorf B, Mischke U, Leßmann D (1998) Chrysophytes and chlamydomonads: pioneer colonists in extremely acidic mining lakes $(\mathrm{pH}<3)$ in Lusatia (Germany). Hydrobiologia 369:315-327

Nogrady T, Segers H (eds) (2002) Rotifera 6: the Asplanchnidae, Gastropodidae, Lindiidae, Microcodinidae, Synchaetidae, Trochosphaeridae. In: Dumont HJ, Nogrady T (eds) Guides to the identification of the microinvertebrates of the continental waters of the world. SPB Academic, The Hague

Nogrady T, Pourriot R, Segers H (1995) Rotifera 3: the Notommatidae and the Scaridiidae. In: Dumont HJ, Nogrady T (eds) Guides to the identification of the microinvertebrates of the continental waters of the world. SPB Academic, The Hague

Pérez-Legaspi IA, Rico-Martínez R (2001) Acute toxicity tests on three species of the genus Lecane (Rotifera: Monogononta). Hydrobiologia 446/447:375-381

Radwan S, Paleolog A (1983) Notes on the rotifers of coal mine water in Eastern Poland. Hydrobiologia 104(1):307-309

Segers H (1995) Rotifera 2: the Lecanidae (Monogononta). In: Dumont HJ, Nogrady T (eds) Guides to the identification of the microinvertebrates of the continental waters of the world. SPB Academic, The Hague

Sienkiewicz E, Gasiorowski M (2015) Influence of acid mine drainage (AMD) on recent phyto-and zooplankton in "the anthropogenic lake district" in south-west Poland. EGU Gen Assem Conf Abstr 17:1764

Steinberg EW, Schafer H, Tittel J, Beisker W (2012) Limnological case studies on acid lakes. Phytoplankton composition and biomass spectra created by flow cytometry and zooplankton composition in mining lakes of different states of acidification. In: Geller W, Klapper H, Salomons W (eds) Acidic mining lakes: acid mine drainage, limnology and reclamation. Springer, Berlin, pp 127-145

Szarek-Gwiazda E (2013) Factors influencing the concentrations of heavy metals in the Raba river and selected Carpathian dam reservoirs. Studia Naturae 60:1-146

Turnau K, Henriques FS, Wołowski K (2009) Differences in metal distribution and concentration in algal species living in a highly acidic, metal-rich pond of a pyrite mine in Portugal. Acta Protozool 48:339-343

Uzarowicz Ł, Skiba S (2011) Technogenic soils developed on mine spoils containing iron sulphides: mineral transformations as an indicator of pedogenesis. Geoderma 163:95-108

Uzarowicz Ł, Skiba S, Skiba M, Michalik M (2008) Mineral transformations in soils on spoil heaps of an abandoned pyrite mine in wieściszowice (Rudawy Janowickie Mts, lower Silesia, Poland). Pol J Soil Sci 41:183-193 
Uzarowicz Ł, Skiba S, Skiba M, Šegvić B (2011) Clay-mineral formation in soils developed in the weathering zone of pyritebearing schists: a case study from the abandoned pyrite mine in Wieściszowice, lower Silesia, Poland. Clays Clay Miner 59:581-594

Weinhoff G (2004) Vertical niche separation of two consumers (Rotatoria) in an extreme habitat. Oecologia 139:594-603

Weinthoff G, Spijkerman E, Kamjunke N, Tittel J (2013) The biology and ecosystems of acidic pit lakes. Trophic interactions and energy flow. In: Geller W, Klapper H, Salomons W (eds) Acidic mining lakes: acid mine drainage, limnology and reclamation. Springer, Berlin, pp 135-149

Wendt-Potthoff K (2013) The biology and ecosystems of acidic pit lakes. Prokaryotic microorganisms, protists, and fungi. In: Geller W, Klapper H, Salomons W (eds) Acidic mining lakes: acid mine drainage, limnology and reclamation. Springer, Berlin, pp 126-135

Woelfl W, Whitton BA (2000) Sampling. preservation and quantification of biological samples from highly acidic environments $(\mathrm{pH}$ 3). Hydrobiologia 433:173-180

Wollmann K, Deneke R, Nixdorf B, Packroff G (2000) Dynamic of planktonic food webs in three mining lakes across a $\mathrm{pH}$ gradient (pH 2-4). Hydrobiologia 433:3-14

Wołowski K, Turnau K, Henriques FS (2008) The algal flora of an extremely acidic, metal-rich drainage pond of Sao Domingos pyrite mine (Portugal). Cryptogam Algol 29(4):313-324

Wołowski K, Uzarowicz Ł, Łukaszek M, Pawlik-Skowrońska B (2013) Diversity of algal communities in acid mine drainages of different physico-chemical properties. Nova Hedwig 97(1-2):117-137 